\title{
FAKTOR-FAKTOR YANG MEMPENGARUHI MINAT MASYARAKAT BERINVESTASI SUKUK
}

\author{
Lilis Yuliati \\ Universitas Jember \\ e-mail: lilis_yuliati@yahoo.co.id
}

\begin{abstract}
Abstact
This study aims to analyze the interrelationship between risk factors and product attributes that affect the public interest in Islamic Sukuk invest SRO01 and to know the appeal of an independent Islamic Bank Sukuk SR001 in selling by investors point of view. The method used in this study is a survey, while the sukuk investor esponden is SR 001, amounting to 100 people. The research was conducted by distributing questionnaires with Likert's scale. The analytical technique used is multiple regression. Based on the results of research and discussion that has been done can be concluded that the risk of investment and product islamic attributes positive effect on the public interest to invest, it is evident from the results of the test statistic, the test $F$ and test $T$.
\end{abstract}

Kajian ini bertujuan untuk menganalisis interrelasi antara faktor-faktor resiko dengan atribut produk yang mempengaruhi minat publik terhadap investasi Sukuk Islam SR001 dan untuk mengetahui daya tarik Sukuk Bank Islam SR001 menurut para investor. Metode yang digunakan dalam kajian ini adalah survei, sementara responden adalah investor sukuk SR 001 sejumlah 100 orang. Penelitian dilaksanakan dengan cara membagi kuisioner dengan skala Likert. Teknik analisis yang digunakan adalah regresi ganda. Berdasarkan hasil penelitian dan diskusi yang dilakukan dapat disimpulkan bahwa resiko investasi dan produk Islami berkait positif dengankeinginan publik untuk melakukan investasi. Ini tampak jelas dari penghitungan statistik dengan test $\mathrm{F}$ dan $\mathrm{T}$.

Keywords: investasi, minat, sukuk, atribut produk islami, BSM 


\section{A. Pendahuluan}

Konsep keuangan berbasis syariah Islam dewasa ini telah diterima secara luas di dunia dan telah menjadi alternatif baik bagi pasar yang menghendaki kepatuhan syariah (shariah compliance). Diawali dengan perkembangan yang pesat di negara-negara Timur Tengah dan Asia Tenggara, produk keuangan dan investasi berbasis syariah Islam saat ini telah diaplikasikan di pasar-pasar keuangan Eropa, Asia, bahkan Amerika Serikat. Selain itu, lembaga-lembaga yang menjadi infrastruktur pendukung keuangan Islam global juga telah didirikan, seperti Accounting and Auditing Organization for Islamic Institution (AAOIFI), International Financial Service Board (IFSB), International Islamic Financial Market (IIFM), dan Islamic Research and Training Institute (IRTI).

Salah satu instrumen keuangan syariah yang telah diterbitkan baik oleh negara maupun korporasi adalah sukuk atau obligasi syariah. Pada saat ini, beberapa negara telah menjadi regular issuer dari sukuk, misalnya Malaysia, Bahrain, Brunei Darussalam, Uni Emirate Arab, Qatar, Pakistan, dan State of Saxony Anhalt-Jerman. Penerbitan sukuk negara (sovereign sukuk) tersebut biasanya ditujukan untuk keperluan pembiayaan negara secara umum (general funding) atau untuk pembiayaan proyek-proyek tertentu, seperti pembangunan bendungan, unit pembangkit listrik, pelabuhan, bandar udara, rumah sakit, dan jalan tol. Selain itu, sukuk juga dapat digunakan untuk keperluan pembiayaan cash-mismatch, yaitu dengan menggunakan sukuk dengan jangka waktu pendek (Islamic Treasury Bills) yang juga dapat digunakan sebagai instrumen pasar uang.

Di Indonesia, sukuk korporasi lebih dikenal dengan istilah obligasi syariah. Pada tahun 2002, Dewan Syariah Nasional mengeluarkan fatwa No: 32/DSN-MUI/IX/2002, tentang Obligasi Syariah. Sebagai tindak lanjut atas fatwa di atas, pada Oktober 2002 PT. Indosat Tbk mengeluarkan obligasi syariah yang pertama kali di pasar modal Indonesia dengan tingkat imbal hasil 16,75\%, imbal hasil ini cukup tinggi dibanding rata-rata return obligasi konvensional. Pada akhir tahun 2009, sedikitnya telah ada 23 perusahaan yang telah menerbitkan obligasi syariah di Indonesia. Total emisi hingga pertengahan 2009 baru mencapai lima triliun rupiah lebih (\$ 500 juta). Dibandingkan dengan Malaysia yang pada pertengahan 2007 saja telah membukukan total emisi RM. 111,5 miliar (\$33 miliar). Menurut Achsien banyak 
tantangan yang dihadapi dalam pengembangan obligasi syariah di Indonesia, diantaranya adalah sosialisasi kepada investor, opportunity cost, aspek likuiditas, sampai regulasi atau perundang-undangan. ${ }^{1}$

Oleh karena itu, untuk membangkitkan gairah investasi, pada tanggal 30 Januari 2009, Pemerintah Republik Indonesia secara resmi mengeluarkan Sukuk ritel berseri SR 001 dengan target penjualan sebesar Rp. 3,4 triliun. SR 001 merupakan instrumen investasi berbasis syariah yang ditujukan untuk pasar ritel. Hasil survei pasar (market intelligence) yang dilakukan Direktorat Jenderal Pengelolaan Utang Negara Departemen Keuangan memperkirakan pasar Sukuk di Indonesia bisa mencapai Rp 15 triliun. Depkeu juga telah menyiapkan aset jaminan (underlying) atas Sukuk tersebut senilai Rp. 18,8 triliun. Terbukti penjualan Sukuk menuai titik cerah, terlebih Bank Mandiri sebagai salah satu agennya telah berhasil menjual SR 001 hingga hari Jum'at, 13 Februari 2009 kepada 3.008 investor senilai Rp. 605,6 miliar, ini berarti telah melampaui target penjualan yang telah ditetapkan, yaitu sebesar Rp. 95 miliar atau sekitar 637\% dari target penjualan. Kesuksesan Bank Syariah Mandiri dalam penjualan Sukuk SR 001 tidak terlepas dari strategi pemasaran yang profesional, dan tidak kalah penting adalah faktor-faktor yang kuat sehingga mempengaruhi minat masyarakat untuk berinvestasi Sukuk SR 001.

Menurut hasil penelitian Syahyuti, menujukkan bahwa 48,3\% dari 1.182 responden menjalin kemitraan antara nasabah dengan bank syariah dikarenakan anggapan faktor keharaman bunga sebagai bentuk lain dari riba, produk-produk yang terhindar dari unsur bunga hanya dimiliki perbankan syariah, sehingga responden memilihnya. ${ }^{2}$ Adapun suatu alasan mengapa para nasabah umumnya akan memilih bank syariah daripada bank-bank lainnya terletak pada kunci keuntungan kompetitif. ${ }^{3}$ Dilihat dari sistem yang dijalankan bank syariah sesuai dengan ajaran Islam, pelayanan dan perlakuan yang diberikan oleh bank syariah menjadi alasan nasabah masih berkeinginan untuk meneruskan kemitraannya dengan bank, hal ini disebabkan dunia perbankan syariah telah mengalami tingkat kompetisi yang tinggi. ${ }^{4}$

\footnotetext{
${ }^{1}$ Achsien, Inggi, Investasi Syariah di Pasar Modal, (Jakarta: Gramedia Pustaka Utama, 2003), h. 23.

${ }^{2}$ Syahyut, "Review dari Sepuluh Penelitian tentang Berbankan Syari'ah," 2005, h. 6, data dapat diperoleh pada web. www.undip.co.id diakses pada tangal 15 Februari 2011.

${ }^{3}$ Ibrahim Warde, Islamic Fiance In the Global Econimy, terj. Andriyadi Ramli, Islamic Fiance: Keuangan Islam dalam Perekonomian Global, (Yogyakarta: Pustaka Pelajar, 2009), h. 324.

${ }^{4} \mathrm{Ibid}, \mathrm{h} .340$.
} 
Pemilihan masyarakat terhadap bank syariah disebabkan adanya keistimewaan-keistimewaan yang membedakan dengan bank konvensional yaitu: ${ }^{5}$ (1) adanya persamaan ikatan emosional yang kuat antara pemegang saham, pengelola bank, dan nasabahnya; (2) diterapkannya sistem bagi-hasil sebagai pengganti bunga akan menimbulkan akibat-akibat yang positif; (3) terdapat fasilitas kredit kebaikan (qard al-hasan) yang bersifat sosial; (4) melekatnya konsep (build in concept) dengan berorientasi pada kebersamaan mendorong investasi, memerangi kemiskinan, membina golongan ekonomi lemah, dan lain-lain; (5) tidak adanya beban biaya di luar kemampuan nasabah dan (6) alternatif sistem ekonomi yang berkeadilan. Sehingga dapat disimpulkan bahwa nasabah pengguna bank syariah dikategorikan kedalam dua bagian yaitu pengguna yang berlandaskan pada ikatan emosional atau solidaritas dan pengguna yang berasaskan keuntungan atau komersial.

Prospektus sukuk (obligasi) menurut Wijaya dapat dilihat dari faktorfaktor yang mempengaruhi laku atau tidaknya obligasi (sukuk) pemerintah, meliputi latar belakang penerbitan obligasi pemerintah serta persepsi investor atas risk premium yang terdiri atas tipe penerbit obligasi, issuer's credit worthiness, jangka waktu jatuh tempo, tingkat besarnya kupon yang diberikan, ada tidaknya opsi yang melekat pada ekuitas, besarnya pajak yang dibebankan, dan terakhir likuiditas dari obligasi. Selain itu, dilihat dari sisi eksternal, kondisi makro ekonomi negara penerbit obligasi juga mempengaruhi keberhasilan penjualan obligasi pemerintah. ${ }^{6}$

Disamping itu atribut-atribut produk yang melekat, dimana atribut ini muncul kerkenaan dengan timbulnya suatu produk. Atribut produk akan mempengaruhi tingakat pengetahuan konsumen sehinga timbullah perilaku pembelian setelah seorang konsumen mengetahui atribut produk yang akan dibeli. Produk yang sesuai dengan prinsip syariah memiliki lima atribut yang melekat yaitu tidak ada transaksi keuangan berbasis bunga (riba), pengenalan pajak religius atau pemebrian sedekah (zakat), pelarangan produksi barang dan jasa yang bertentangan dengan sistem nilai Islam, penghindaran aktivitas yang melibatkan maysir (judi) dan gharar (ketidakpastian), dan ter-

\footnotetext{
${ }^{5}$ Warkum Sumitro, Asas-asas Perbankan Islam dan Lembaga-lembaga Terkait (BAMUI, Takaful, dan Pasar Modal Syariah) di Indonesia, (Jakarta: Raja Grafindo Persada, 2004), h. 22-25.

${ }^{6}$ Krisna Wijaya dan Djoko Retnadi, Konsolidasi Perbankan Nasional: Dari Rekapitalisasi Menuju Arsitektur Perbankan Indonesia (API), (Jakarta: Masyarakat Profesional Madani, 2005), h. 14.
} 
akhir penyediaan takāful (asuransi Islam). ${ }^{7}$ Oleh karena itu tujuan penelitian adalah untuk mengetahui pengaruh faktor risiko dan atribut produk islami terhadap minat minat masyarakat berinvestasi Sukuk SR001.

Penelitian ini merupakan penelitian yang menggunakan pendekatan kuantitatif, kelebihan dari kuantitatif adalah sebagai alat ukur untuk menguji dugaan atau hepotesis dari kualitatif, serta memberikan justifikasi signifikan terhadap temuan penelitian berdasarkan uji statistik. ${ }^{8}$ Metode yang digunakan dalam penelitian adalah survey, yaitu suatu metode pengumpulan data primer dengan memberikan pertanyaan-pertanyaan kepada responden individu. ${ }^{9}$ Responden adalah investor sukuk SR 001 melalui agen Bank Syariah Mandiri Cabang Jember, Banyuwangi dan Situbondo yang berjumlah 100 orang. Metode pengumpulan data primer pada penelitian ini dilakukan dengan metode sensus, metode ini mendasarkan pada laporan tentang diri atau self report, atau setidak-tidaknya pada pengetahuan dan atau keyakinan pribadi. ${ }^{10}$ Pelaksanaan metode angket dalam penelitian ini dilaksanakan dengan cara menyebarkan kuesioner pada responden secara langsung, responden diminta memberikan pendapat atau jawaban berupa kuesioner tertutup. Pengukuran kuesioner digunakan skala Likert's yaitu pengukuran kuesioner berdasarkan tanggapan atau respon seseorang tantang objek sosial dimana tiap instrumen jawaban mempunyai gradasi dari 1 - $5 .{ }^{11}$

Sedangkan teknik yang peneliti gunakan untuk mengambil data dari responden menggunakan teknik convenience random sampling. Artinya adalah teknik pengambilan sampel dengan pendekatan responden yang mudah ditemui dan mau menjadi narasumber, data itulah yang menjadi rujukan peneliti. Hal ini dikarenakan jumlah responden sangat banyak dan tersebar di berbagai penjuru wilayah. Pemilihan metode convenience random sampling dikarenakan metode ini cocok untuk menguji atau mencari ide-ide baru yang bersifat ekploratif. ${ }^{12}$

\footnotetext{
${ }^{7}$ Mervin K. Lewis dan Latifa M. Algaoud, Perbankan Syari'ah Prinsip, Praktik, dan Prospek, terjem, (Jakarta: Serambi Ilmu Semesta, 2005), h. 48.

${ }^{8}$ Ibid, h. 38-39.

9 Jogiyanto, Metodologi Penelitian Bisnis: Salah Kaprah dan Pengalaman-pengalaman, (Yogyakarta: BPFE, 2004), h. 115.

${ }^{10}$ Sutrisno Hadi, Metodologi Research, (Yogyakarta: Andi Offset, 2001), h. 157.

${ }^{11}$ Suliyanto, Metode Riset Bisnis, (Yogyakarta: Andi Offset, 2006), h. 82-83.

12 Ibid, h. 124.
} 
Teknik analisi data yang digunakan adalah regresi berganda (multiple regression) dengan persamaan sebagai berikut ini.

$$
\begin{aligned}
& \mathrm{Y}=\mathrm{a}+\mathrm{b}_{1} \mathrm{X} 1+\mathrm{b}_{2} \mathrm{X} 2+\mathrm{e} \\
& \text { Keterangan: } \\
& \mathrm{Y}=\text { Minat Masyarakat } \\
& \mathrm{a}=\text { konstansta } \\
& \mathrm{X} 1=\text { Risiko Investasi } \\
& \mathrm{X} 2=\text { Atribut Produk Islami } \\
& \mathrm{B}_{1,2}=\text { Koefisien Regresi } \\
& \mathrm{e}=\text { Error }
\end{aligned}
$$

\section{B. Faktor-faktor yang Mempengaruhi Investasi}

Beberapa komponen yang mempengaruhi keuntungan yang diharapkan dari investasi dapat digolongkan menjadi dua faktor, pertama faktor objektif dan kedua faktor subjektif. Faktor objektif meliputi teknologi, harga relatif faktor produksi, dan permintaan akan barang-barang pada masa akan datang, sedangkan faktor subjektif adalah pengalaman yang dialami investor baik positif maupun negatif karena bersikap paradoksial.

Ketidakpastian dunia telah menciptakan rel tentang aturan yang disebut Rule of Thumb (aturan main yang berdasarkan pengalaman dan intuisi) ${ }^{13}$ sering kali berguna sebagai pedoman, karena masa depan dapat diperoyeksi sama dengan hari kemarin. Maka dari itu, investor tidak bisa selamanya menggunakan aturan ini untuk memperoleh keuntungan dimasa yang akan datang, sehingga penentuan objektivitas dan subjektivitas tidak dapat dinafikan.

\section{Atribut Instrumen Islami}

Faktor penting dalam menentukan pilihan investasi pada instrumen obligasi dilihat dari sisi risiko menurut Rahman antara lain: ${ }^{14}$ default risk

\footnotetext{
${ }^{13}$ Iswardono, Uang dan Bank, (Yogyakarta: BPFE, 1996), h. 234.

${ }^{14}$ Arif Rahman, Pilihan Investasi Paling Mak Nyuss, (Yogyakarta: Media Pressindo, 2009), h. 6365.
} 
(risiko gagal bayar), tingkat suku bunga, risiko pembelian kembali (call risk), biaya Investasi, pengaruh deposito, risiko likuiditas, inflasi dan atribut instrumen islami. Pasar modal sebagai salah satu kegiatan ekonomi modern dapat dikonversikan ke dalam lembaga keuangan syariah, dimana hal itu merupakan bagian dari sistem ekonomi Islam. Prinsip utama lembaga keuangan syariah adalah bebas bunga yang tercermin dalam produk-produk yang dihasilkannya. Dalam kaitan pasar modal, produk yang dihasilkan disebut instrumen, yaitu semua surat berharga yang diperdagangkan di bursa dan bentuknya beraneka ragam. Instrumen yang telah dinilai DSN MUI memenuhi prinsip syariah adalah saham dan obligasi.

Model sikap multi atribut dari Fishbein menggambarkan ancangan yang berharga untuk mengetahui hubungan diantara pengetahuan produk yang dimiliki konsumen dan sikap terhadap produk berkenaan dengan ciri atau atribut produk. ${ }^{15}$ Menurut Kotler, produk meliputi objek fisik, pelayanan, orang, tempat organisasi dan gagasan. ${ }^{16}$ Sedangkan atribut produk adalah faktor yang melekat pada suatu produk. Keputusan mengenai atribut produk merupakan unsur-unsur produk yang dipandang penting oleh konsumen dan dijadikan dasar dalam keputusan pembelian. Mowen dalam Rahman menyatakan bahwa tingkat performance produk dapat diukur atau dilihat pada tingkat kepentingannya berdasarkan atribut-atribut kunci yang sudah diidentifikasi oleh konsumen. Oleh karena itu, atribut produk merupakan titik tolak penilaian bagi konsumen tentang terpenuhi atau tidaknya kebutuhan dan keinginan konsumen yang diharapkan dari suatu produk yang sebenarnya, maka dapat diidentifikasikan atribut-atribut yang menyertai suatu produk. ${ }^{17}$

Atribut-atribut produk yang mencerminkan islami dari lembaga keuangan syariah untuk dijadikan ukuran adalah: produk yang mencirikan menghindari unsur riba, hasil investasi dibagi menurut bagi hasil atau fee (akad persekutuan dan pertukaran), menghindari unsur ketidakpastian (gharar),

\footnotetext{
${ }^{15}$ F. James Engel, Roger D. Blackwell, dan Paul W. Miniard, Perilaku Konsumen, (Jakarta: Binarupa Aksara, 1994), h. 60.

${ }^{16}$ Phillip Kotler, Manajemen Pemasaran, edisi Bahasa Indonesia, (Jakarta: Pearson Education Asia Pte. Ltd. dan PT Prenhlmlindo, 2000), h. 448.

${ }^{17}$ Lihat Rahman El-Junusi, "Pengaruh Atribut Produk Islam, Komitmen Agama, Kualitas Jasa dan Kepercayaan terhadap Kepuasan dan Loyalitas Nasabah Bank Syari'ah (pada Bank Muamalat Kota Semarang)," paper dipublikasikan pada acara The 9-th Annual Conference on Islamic Studies (ACIS), Surakarta, 2-5 November 2009, h. 2.
} 
menghindari unsur gambling atau judi (maysir), melakukan investasi yang halal, dan melakukan aktivitas sesuai dengan syariah sebagaimana yang disebutkan Iqbal dalam Muhamad.18

\section{Minat terhadap Sukuk}

Minat dalam Kamus Besar Bahasa Indonesia diartikan sebagai kecenderungan hati yang tinggi terhadap sesuatu gairah, keinginan. ${ }^{19}$ Minat adalah kecenderungan seseorang untuk memilih melakukan suatu kegiatan tertentu diantara sejumlah kegiatan lain yang berbeda. ${ }^{20}$ Minat merupakan kecenderungan afektif seseorang untuk membuat pilihan aktivitas, kondisikondisi individual dapat merubah minat seseorang. Sehingga dapat dikatakan minat itu tidak stabil sifatnya. ${ }^{21}$ Sedangkan menurut Whiteringten minat adalah kecenderungan seseorang untuk memilih dan melakukan suatu kegiatan tertentu diantara sejumlah kegiatan lain yang tersedia. ${ }^{22}$

Sesuai dengan pengertian di atas maka dapat disimpulkan bahwa minat adalah fungsi kejiwaan atau sambutan yang sadar untuk tertarik terhadap suatu objek baik berupa benda atau yang lain. Selain itu minat dapat timbul karena ada gaya tarik dari luar dan juga datang dari hati sanubari. Minat yang besar terhadap suatu hal merupakan modal yang besar untuk mencapai tujuan yang diminati dalam hal ini berinvestasi terutama di sektor pasar modal.

Menurut pendapat dari Abu Ahmadi dan Widodo Supriyono disadur Harnanto, ada beberapa ciri-ciri minat yang dapat didefinisikan, antara lain: (1) cara mengikuti aktivitas pada dunia yang diminati; (2) serius tidaknya dalam mengikuti aktivitas. ${ }^{23}$ Seseorang yang berminat melakukan aktivitas investasi seperti pembelian saham, obligasi, reksadana, atau berinvestasi melalui pasar uang seperti deposito atau giro tidak akan mengenal putus asa dan tetap menikmati kegiatan tersebut, bahkan dengan sendirinya ia akan mencari informasi seluas mungkin tanpa mengandalkan orang lain.

${ }^{18}$ Muhamad, Dasar-dasar Keuangan Islami, (Yogyakarta: Ekonisia, 2004), h. 52.

${ }^{19}$ Anton M. Moeliono, dkk., Kamus Besar Bahasa Indonesia, (Jakarta: Balai Pustaka, 1999), h. 225.

${ }^{20}$ Saparinah, dkk., Psikologi Olahraga: Buku Tuntunan, (Jakarta: Depdikbud, 1982), h. 10.

${ }^{21}$ Muhaimin, "Korelasi Minat Belajar Pendidikan Jasmani terhadap Hasil Belajar Pendidikan Jasmani," Skripsi, tidak dipublikasikan, (Semarang: IKIP, 1994), h. 4.

${ }^{22}$ H. C. Whiteringten, Psikologi Pendidikan, terj. M. Buchari, (Jakarta: Aksara Baru, 1982), h. 122.

23 Harnanto, "Survai Minat Siswa SLTP Negeri dan Swasta Kecamatan Bantarkawung Kabupaten Brebes terhadap Ekstrakurikuler Bola Voli Tahun Ajaran 2004/2005, Skripsi, (Semarang: Unversitas Negeri Semarang, Fakultas Ilmu Keolahragaan, 2006), h. 8. 
Dorongan yang ada pada diri individu, menggambarkan perlunya perlakuan yang luas, sehingga ciri-ciri terlihat lebih terinci dan jelas sesuai dengan faktor kebutuhan. Oleh karena itu ciri-ciri dan minat seseorang akan menjadi pedoman penyelenggara program aktivitas dalam berinvestasi dan arahnya akan lebih dikategorikan kepada hasil investasi berupa: tingkat pengembalian yang besar, aman, terpercaya, dan domain yang lain. Dengan adanya penggunaan pedoman maka pandangan dan pengembangan program akan sesuai dengan ketepatan masa berinvestasi dalam melakukan aktivitas investasi. Kemudian diharapkan akan muncul dalam pikiran, bahwa pada umumnya seseorang memiliki ragam tentang pengertian berinvestasi sehat dan aman yang perlu diperhatikan.

Dalam pelaksanaannya, penentuan minat terdapat beberapa macam ekspresi, yaitu:24 (1) Minat yang diekspresikan seseorang dapat mengungkapkan minat atau pilihannya dengan kata-kata tertentu; (2) Minat yang diwujudkan seseorang dapat mengungkapkan minat bukan melalui kata-kata, tetapi melalui tindakan atau perbuatan ikut berperan aktif dalam suatu aktivitas; (3) Minat yang diinvestasikan seseorang dalam penilaian minat dapat diukur dengan jawaban terhadap berbagai pertanyaan tertentu atau secara berurutan. Pilihan untuk kelompok aktivitas tertentu, susunan pertanyaan ini disebut investasi minat; (4) Minat masyarakat dapat diartikan sebagai kecenderungan terhadap sesuatu yang muncul dari dalam individu dan telah menjadi kebiasaan umum dalam lingkungan masyarakat. Yang bisa diukur dengan faktor yang menentukan minat individu.

Untuk melihat indikator dari seseorang berminat atau tidak maka dibutuhkan deskripsi yang jelas mengenai keberminatan seseorang, hal ini bisa kita lihat dari keaktifan seseorang dalam mencari informasi, mengidentifikasi semua persoalan yang di minati, menganalisis, dan membuat daftar tabel tentang sesuatu yang di minati hingga penetapan bidang yang diminati.

Surat Berharga Syariah Negara selanjutnya disingkat SBSN, atau dapat disebut Sukuk Negara, adalah surat berharga negara yang diterbitkan berdasarkan prinsip syariah, sebagai bukti atas bagian penyertaan terhadap Aset SBSN, baik dalam mata uang rupiah maupun valuta asing. Proses pembeliannya berdasarkan akad yaitu perjanjian tertulis yang tidak bertentangan

${ }^{24}$ Muhaimin, “Korelasi Minat Belajar....” h. 10. 
dengan prinsip syariah dan sesuai dengan peraturan perundang-undangan. Terdiri atas akad Ijarah adalah Akad yang satu pihak bertindak sendiri atau melalui wakilnya menyewakan hak atas suatu aset kepada pihak lain berdasarkan harga sewa dan periode sewa yang disepakati.

Akad Mudarabah adalah akad kerja sama antara dua pihak atau lebih, yaitu satu pihak sebagai penyedia modal dan pihak lain sebagai penyedia tenaga dan keahlian, keuntungan dari kerjasama tersebut akan dibagi berdasarkan nisbah yang telah disetujui sebelumnya, sedangkan kerugian yang terjadi akan ditanggung sepenuhnya oleh pihak penyedia modal, kecuali kerugian disebabkan oleh kelalaian penyedia tenaga dan keahlian.

Akad Musharakah adalah akad kerja sama antara dua pihak atau lebih untuk menggabungkan modal, baik dalam bentuk uang maupun bentuk lainnya, dengan tujuan memperoleh keuntungan, yang akan dibagikan sesuai dengan nisbah yang telah disepakati sebelumnya, sedangkan kerugian yang timbul akan ditanggung bersama sesuai dengan jumlah partisipasi modal masing-masing pihak.

Terakhir Istisna' adalah akad jual beli aset berupa objek pembiayaan antara para pihak dimana spesifikasi, cara dan jangka waktu penyerahan, serta harga aset tersebut ditentukan berdasarkan kesepakatan para pihak. ${ }^{25}$

Tanggal 30 Januari 2009, pemerintah berdasarkan ketentuan dari Departemen Keuangan, Negara mengeluarkan Surat Berharga Syariah Negara berseri SR 001 dengan target penjualan sebesar 15 triliun dengan jaminan aset (underlying) negara sebesar 18,8 triliun.

Sukuk Negara adalah Surat Berharga Syariah Negara (Sukuk) yang diterbitkan pemerintah Republik Indonesia dengan tujuan tertentu, memperluas basis sumber pembiayaan anggaran negara, mendorong pengembangan pasar keuangan syariah, menciptakan benchmark di pasar keuangan syariah, diversifikasi basis investor, mengembangkan alternatif instrumen investasi, mengoptimalkan pemanfaatan barang milik negara, dan memanfaatkan dana-dana masyarakat yang belum terjaring oleh sistem perbankan konvensional.

${ }^{25}$ Undang-Undang Republik Indonesia No. 19 Tahun 2008 tentang Surat Berharga Syariah Negara, pasal 1, ayat 1, 6, 7, 8, dan 9. 
Keunggulan Sukuk Negara sebagai instrumen investasi diantaranya pertama, aman, artinya mengingat pembayaran pokok dan imbalan sampai dengan jatuh tempo dijamin oleh Negara. Kedua, menguntungkan, yaitu pada saat diterbitkan, imbalan atau kupon yang ditawarkan lebih tinggi dibandingkan rata-rata tingkat bunga deposito bank BUMN, tingkat imbalan atau kupon tetap sampai dengan saat jatuh tempo, kupon dibayarkan setiap bulan. Ketiga, likuid, dimana sukuk ini dapat diperdagangkan serta berpotensi memperoleh Capital Gain bila sukuk dijual pada harga yang lebih tinggi daripada harga beli, Sukuk juga dapat dijadikan sebagai agunan atau digadaikan kepada pihak lain (di Bank Mandiri, hingga saat ini penggunaan sukuk sebagai agunan kredit masih dalam tahap pengembangan), dan keempat penerbitannya sesuai dengan prinsip syariah dan telah mendapatkan fatwa serta opini syariah dari Dewan Syariah Nasional Majelis Ulama Indonesia

Sukuk Ritel Seri SR 001 adalah Sukuk Negara yang ditujukan bagi investor ritel perorangan (individu) Warga Negara Indonesia saat peluncuran di pasar perdana, kemudian dapat diperdagangkan bagi investor individual maupun institusi di pasar sekunder. Karakteristik umum bersekala nasional mengenai sukuk RS $001^{26}$ sebagaimana diterangkan tabel 1 .

Tabel 1.

Pokok-pokok ketentuan dan Persyaratan Sukuk SR 001

\begin{tabular}{|l|l|}
\hline Nama Sukuk & Sukuk Negara Ritel Seri SR 001 \\
\hline Kode Sukuk & SR 001 \\
\hline Nominal Penerbitan & Rp. 5.556.290.000.000,00 \\
\hline Kode ISIN & IDJ000003009 \\
\hline Pembayaran Imbalan/Kupon Pertama & Tanggal 25 Maret 2009 \\
\hline Pembayaran Imbalan/Kupon & Tanggal 25 setiap bulan \\
\hline Jenis Imbalan/Kupon & Tetap \\
\hline Frekwensi Pembayaran Imbalan/Kupon & Bulanan \\
\hline Imbalan/Kupon & $12 \%$ per tahun \\
\hline Tanggal Jatuh Tempo & 12 Februari 2012 \\
\hline \multicolumn{2}{|c|}{ Sumber: Departemen Keuangan RI 2009}
\end{tabular}

26 Surat Pengumuman Hasil Penerbitan Sukuk Negara Ritel Seri SR 001 No. Peng00162/BEI.PSU/02-2009, Departemen Keuangan Republik Inonesia. 
Acuan dasar penelitian ini mendasarkan atas penelitian yang telah dilakukan oleh peneliti sebelumnya, hal ini dimaksudkan untuk kesesuaian model yang dibangun dalam penelitian. Sehingga model yang didapat dapat digunakan untuk menerangkan variabel penelitian.

Penelitian Wahyudi Widodo pada skripsinya yang berjudul "Faktorfaktor yang Mempengaruhi Permintaan Obligasi Korporasi di Indonesia" menyatakan bahwa variabel tingkan suku bunga dan deposito secara bersama-sama mempunyai pengaruh negatif terhadap permintaan obligasi korporasi di Indonesia. ${ }^{27} \mathrm{Hal}$ ini senada dengan penelitian yang dilakukan oleh Eni Setyowati dan Siti Fatimah NH yang berjudul "Analisis Faktor-faktor yang Mempengaruhi Investasi Dalam Negeri di Jawa Tengah Tahun 1980-2002" menunjukkan hasil berdasarkan estimasi jangka panjang bahwa variabel yang berpengaruh dan signifikan secara statistik adalah variabel suku bunga mempunyai pengaruh yang negatif terhadap investasi dalam negeri. ${ }^{28}$

Nur Fauziah dan Adistien Fatma Setyarini dalam penelitiannya yang berjudul "Analisis Faktor-faktor yang Mempengaruhi Yield Obligasi Perusahaan (Studi Kasus Pada Industri Perbankan Dan Industri Finansial)" menjelaskan bahwa likuiditas perpengaruh positif terhadap yield obligasi, sedangkan call risk (buyback) dan inflasi berpengaruh negatif terhadap yield obligasi. ${ }^{29}$

Selain faktor risiko yang mempengaruhi minat masyarakat untuk berinvestasi memaliu sukuk, faktor atribut produk yang bernuansakan islami juga tidak bisa dinafikan. Sebagaimana penelitian Rahman El-Junusi yang berjudul "Pengaruh Atribut Produk Islam, Komitmen Agama, Kualitas Jasa dan Kepercayaan terhadap Kepuasan dan Loyalitas Nasabah Bank Syariah (pada Bank Muamalat Kota Semarang)" menyimpulkan melalui analisis konfirmatori hasil investasi menurut bagi hasil, menghindari judi dan investasi yang halal merupakan atribut produk menjadikan unsur-unsur produk yang di-

\footnotetext{
${ }^{27}$ Wahyudi Widodo, "Faktor-faktor yang Mempengaruhi Permintaan Obligasi Korporasi di Indonesia', Skripsi, (Bandar Lampung: Universitas Lampung), 2009.

${ }^{28}$ Eni Setyowati dan Siti Fatimah NH, “Analisis Faktor-faktor yang Mempengaruhi Investasi Dalam Negeri di Jawa Tengah Tahun 1980-2002," Jurnal Ekonomi Pembangunan, No. 1, Vol. 8, 2007, Surakarta, 2007.

${ }^{29}$ Nur Fauziah dan Adistien Fatma Setyarini, "Analisis Faktor-faktor yang Mempengaruhi Yield Obligasi Perusahaan (Studi Kasus pada Industri Perbankan dan Industri Finansial)," Jurnal Siasat Bisnis, No. 9, Vol. 2, 2004, Jakarta, 2004.
} 
pandang penting oleh nasabah dan dijadikan dasar dalam keputusan untuk mengadakan hubungan dengan Bank Muamalat Cabang Semarang. ${ }^{30}$ Oleh karena itu kerangka pemikiran dalam penelitian dapat dijelaskan pada gambar berikut.

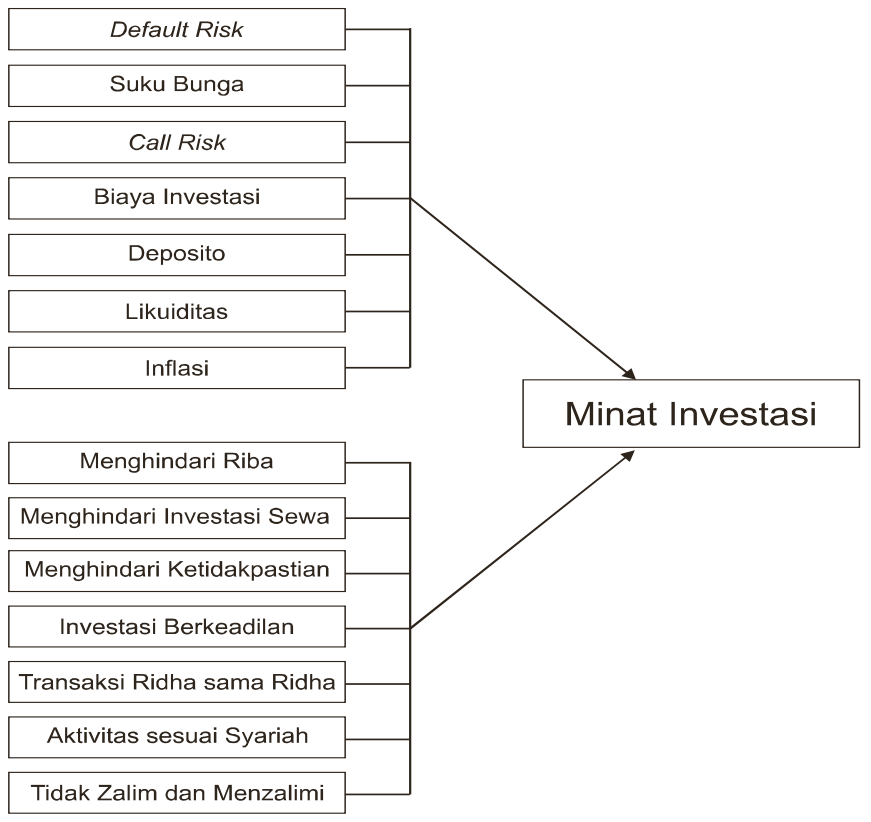

Gambar 1.

Kerangka Pemikiran Penelitian

\section{E. Pembahasan}

Berdasarkan hasil tabulasi penelitian yang dilakukan kepada 126 responden, yang mengisi lengkap kuesioner 100 responden sedangkan 26 tidak lengkap. Adapun profil responden dapat dijelaskan sebagai berikut:

${ }^{30}$ Rahman El-Junusi, "Pengaruh Atribut Produk Islam, Komitmen Agama, Kualitas Jasa dan Kepercayaan terhadap Kepuasan dan Loyalitas Nasabah Bank Syari'ah (pada Bank Muamalat Kota Semarang), paper dipublikasikan pada acara The $9^{\text {th }}$ Annual Conference on Islamic Studies (ACIS), Surakarta, 2009. 
Tabel 2.

Profil Responden Menurut Jenis Kelamin dan Umur

\begin{tabular}{lc}
\hline \multicolumn{1}{c}{ Kriteria } & Prosentase \\
\hline Laki-laki & 57 \\
Perempuan & 43
\end{tabular}

\begin{tabular}{cc}
\hline Kriteria & Prosentase \\
\hline$<25$ & 5 \\
$25-35$ & 16 \\
$35-45$ & 31 \\
$45-55$ & 33
\end{tabular}

Jumlah 100

\begin{tabular}{cc}
$>55$ & 15 \\
\hline Jumlah & $\mathbf{1 0 0}$ \\
\hline
\end{tabular}

Sumber: Data penelitian diolah.

Tabel 3.

Profil Responden Menurut Pendidikan dan Pekerjaan

\begin{tabular}{|c|c|c|c|}
\hline Kriteria & Prosentase & Kriteria & Prosentase \\
\hline SMA & 9 & Pelajar, & 3 \\
\hline Akademi (D3) & 10 & Mahasiswa & 48 \\
\hline Sarjana & 55 & Wiraswasta & 30 \\
\hline Pascasarjana & 26 & Swasta & 10 \\
\hline (S2/S3) & & PNS,TNI/POLRI, Lainnya & 9 \\
\hline Jumlah & 100 & Jumlah & 100 \\
\hline
\end{tabular}

Sumber: Data penelitian diolah.

Tabel 4.

Profil Responden Menurut Sektor Pekerjaan dan Pendapatan

\begin{tabular}{lc}
\hline \multicolumn{1}{c}{ Kriteria } & Prosentase \\
\hline Perdagangan & 42 \\
Jasa & 31 \\
Transportasi \& Komunikasi & 15 \\
Lainnya & 12 \\
\hline & 100 \\
\hline
\end{tabular}

\begin{tabular}{cc}
\hline Kriteria & Prosentase \\
\hline$<2.000 .000$ & 3 \\
$2.000 .000-4.000 .000$ & 12 \\
$4.000 .000-6.000 .000$ & 27 \\
$>6.000 .000$ & 58 \\
\hline & 100 \\
\hline
\end{tabular}

Sumber: Data penelitian diolah. 
Tabel 5.

Profil Responden Berdasarkan Besaran Investasi pada Sukuk SR 001

\begin{tabular}{cc}
\hline Kriteria & Prosentase \\
\hline$<$ Rp 10.000.000 & 11 \\
Rp. $10.000 .000-$ Rp. 15.000 .000 & 46 \\
Rp. $20.000 .000-$ Rp. 35.000 .000 & 34 \\
$>$ Rp. 35.000 .000 & 9 \\
\hline
\end{tabular}

Sumber: Data penelitian diolah.

Berdasarkan jawaban yang diperoleh dari 100 responden yang merupakan investor SR 001 yang melakukan pembelian pada Bank Syariah Mandiri, dilakukan analisis dengan menggunakan metode regresi linier berganda antara Risiko Investasi dan Atribut Islami dengan Minat Berinvestasi oleh Investor. Pengolahan data dilakukan dengan program SPSS for Windows Versi 16.0 data yang digunakan dianalisis dan disajikan dalam tabel berikut:

Tabel 6.

Perhitungan dan Pengujian Koefisien Determinan

\begin{tabular}{cccccc}
\hline Model & $\mathbf{R}$ & $\boldsymbol{R}$ Square & $\begin{array}{c}\text { Adjusted } \\
\text { RSquare }\end{array}$ & $\begin{array}{c}\text { Std. Error of } \\
\text { the Estimate }\end{array}$ & $\begin{array}{c}\text { Durbin- } \\
\text { Watson }\end{array}$ \\
\hline 1 & $.703(\mathrm{a})$ & .494 & .468 & .521 & 2.304 \\
\hline \multicolumn{5}{c}{ Sumber: Data penelitian diolah. }
\end{tabular}

Berdasarkan tabel 6 menunjukkan bahwa Risiko Investasi dan Atribut Produk Islami serta pengaruhnya terhadap Minat menjadi investor dapat diketahui dengan menghitung nilai koefisien regresi. Perhitungan ini menghasilkan koefisien korelasi antara kedua variabel tersebut sebesar 0,703 atau 70,3\%. Hal ini dapat diinterpretasikan bahwa antara variabel Risiko Investasi dan variabel Atribut Produk Islami serta pengaruhnya terhadap Minat menjadi investor terdapat hubungan yang erat dan sifatnya positif atau searah dengan keeratan hubungan 70,3\%. Peningkatan atas keamanan terhadap risiko investasi dan meningkatnya kekhasan atribut produk islami secara keseluruhan akan meningkatkan pula keputusan investor untuk membeli kembali sukuk. 
Berdasarkan hasil analisis regresi linear (linear regression) yang terdapat dalam lampiran, koefisien determinasi $\left(\mathrm{R}^{2}\right)$ merupakan koefisien yang dipergunakan untuk mengetahui besarnya kontribusi variabel independen terhadap perubahan variabel dependen. Dengan menggunakan rumus Adjusted $R$ Square didapatkan koefisien determinasi yang telah disesuaikan antara kedua variabel tersebut sebesar 0,494 atau 49,4\%. Artinya variabel minat investasi dapat dijelaskan oleh variabel risiko investasi dan atribut produk islami sebesar 49,4\% sedangkan sisanya dijelaskan oleh faktor lain yang tidak masuk dalam model penelitian. Dengan kata lain, kontribusi atau pengaruh variabel independen (Risiko Investasi dan Atribut Produk Islami) terhadap variabel dependent (Minat Berinvestasi) adalah sebesar 49,4\% sedangkan 50,6\% dipengaruhi oleh variabel lain.

Hasil temuan dilapangan diketahui bahwa selain model yang diteliti, ternyata faktor pengetahuan investor terhadap instrumen investasi sangat mempengaruhi terhadap minat investasi, hal ini disebabkan masih minimnya pemahaman investor terhadap instrumen investasi di pasar modal, bahkan pemahaman mereka terhadap sukuk SR 001 masih sangat dangkal. Faktor lain yang juga dipandang penting peneliti adalah pengenalan investor terhadap lembaga investasi pasar modal (perusahaan scuritas) hal ini menjadi landasan bagi investor membeli sukuk SR 001 melalui Bank Syariah Mandiri dikarenakan ketidakkenalan investor terhadap perusahaan scuritas.

Dan terakhir adalah faktor promosi dan iklan dalam dunia investasi di pasar modal. Sebagaimana peran perbankan dalam mengedukasi pasar melalui program promosi dan iklan, sehingga total pemilik rekening di seluruh Indonesia mencapai 60 juta rekening bank. Sedangkan pemegang rekening Efek dan pemegang unit penyertaan Reksa Dana, hanyalah sekitar 600 ribu atau hanya $0,1 \%$ dari jumlah penduduk Nusantara.

Berdasarkan tabel Analysis of Variance (ANOVA) diketahui bahwa model yang terbentuk mempunyai nilai $F=18,576$ dengan signifikansi 0,000. Pengujian dengan membandingkan $F_{\text {tabel }}=3,24$ dengan $\alpha=5 \%(0,05)$ Dengan demikian diketahui bahwa $F_{\text {hitung }}>F_{\text {tabel }}(18,576>3,240)$, serta nilai signifikansi 0,000 < dari 0,05 (5\%) Oleh karena itu bisa dinyatakan bahwa $\mathrm{H}_{\mathrm{o}}$ ditolak. Jadi dapat ditarik kesimpulan dari uji ini bahwa secara bersama-sama (simultan) terdapat pengaruh yang positif dan signifikan antara variabel 
Risiko Investasi dan Atribut Produk Islami dengan Minat Berinvestasi investor.

Koefisien regresi parsial atau uji T digunakan untuk menjawab rumusan masalah untuk menguji pengaruh Risiko Investasi terhadap Minat Berinvestasi dan untuk mengkaji pengaruh Atribut Produk Islami terhadap Minat Berinvestasi. Perhitungan koefisien regresi parsial untuk mengetahui keberartian pengaruh dari setiap variabel dijelaskan pada tabel 7 .

Tabel 7.

Perhitungan dan Pengujian Koefisien Regresi Parsial Coefficients

\begin{tabular}{llccccc}
\hline & Varibel & $\begin{array}{c}\text { Unstandardized } \\
\text { Coefficients }\end{array}$ & $\begin{array}{c}\text { Standardized } \\
\text { Coefficients }\end{array}$ & t & Sig. \\
\hline & B & Std. Error & Beta & & \\
\hline 1 & (Constant) & $-1,823$ &, 919 & & $-1,984$ &, 055 \\
2 & Resiko &, 412 &, 147 &, 323 & 2,804 &, 008 \\
3 & Atribut &, 879 &, 163 &, 623 & 5,401 &, 000 \\
& Islam & & & & & \\
\hline
\end{tabular}

Sumber: Data penelitian diolah.

Dari hasil uji t terhadap koefisien parsial di atas dapat disimpulkan bahwa variabel X2 yaitu Atribut Produk Islami lebih dominan pengaruhnya serta positif terhadap Minat Berinvestasi Sukuk SR 001 daripada variabel Risiko Investasi. Tingkat signifikansinya sebesar 0,000. Pengujian variabel $\mathrm{X}_{1}$ dengan membandingkan $\mathrm{T}_{\text {tabel }}=1,690$ dengan $\alpha=5 \%(0,05)$ Dengan demikian diketahui bahwa $\mathrm{T}_{\text {hitung }}>\mathrm{T}_{\text {tabel }}$ yaitu 2,804 $>1,690$, serta nilai signifikansi $0,008<0,05(5 \%)$. Oleh karena itu bisa dinyatakan bahwa $\mathrm{H}_{\mathrm{o}}$ ditolak. Dan dikatakan bahwa ada pengaruh positif dan signifikan antara Risiko Investasi dengan Minat Berinvestasi SR 001, tingkat pengaruhnya sebesar 41,2\%.

Adapun pengujian variabel $\mathrm{X}_{2}$ dengan membandingkan $\mathrm{T}_{\text {tabel }}=1,690$ dengan $\alpha=5 \%(0,05)$ Dengan demikian diketahui bahwa $\mathrm{T}_{\text {hitung }}>\mathrm{T}_{\text {tabel }}$ yaitu $5,401>1,690$, serta nilai signifikansi 0,000 < 0,05 (5\%). Oleh karena itu bisa dinyatakan bahwa $\mathrm{H}_{\mathrm{o}}$ ditolak dan menerima $\mathrm{H}_{1}$. Maka dinyatakan bahwa terdapat pengaruh positif dan signifikan antara variabel Atribut Produk Islami dengan Minat Berinvestasi SR 001. Dengan tingkat pengaruhnya sebesar $87,9 \%$. 
Alasan mengapa variabel Risiko Investasi memiliki pengaruh yang signifikan karena responden beranggapan bahwa Sukuk SR 001 milik pemerintah Indonesia dianggap aman, dimana investor telah mengetahuinya berdasarkan brosur yang di dapat dari BSM. Risiko yang melekat pada SR 001 diklasifikasikan menjadi 2 yaitu pertama risiko pasar (Market Risk) suatu potensi kerugian dimana investor ketika menjualnya di pasar sekunder ketika terjadi kenaikan tingkat suku bunga. Risiko ini tidak akan terjadi karena sampai saat ini tingkat bunga bank yang di patok BI rate cenderung turun. Bahkan tingkat besaran bunga deposito semakin turun seiring dengan menurunnya BI rate, serta pendapatan bagi hasil dan profit margin dari deposito pada bank syariah tidak sebesar profit margin atau yield yang dihasilkan sukuk SR 001. Sehingga investor masih memburu investasi yang hasilnya lebih besar dari bunga bank. Terbukti bahwa sesaat setelah pencatatan di Bursa Efek Jakarta harga SR 001 naik sebesar 30 basis poin atau harganya menjadi 100,30\% par dengan volume 55 miliar.

Kedua adalah risiko likuiditas, dimana ketika investor membutuhkan dan tunai sehingga menjual SR 001 dengan harga ajar dan di bawah par. Dari sumber berita yang dikutip di atas, terlihat investor tidak mengalami kerugian karena sukuk SR 001 tidak digolongkan dalam instrumen yang kurang likuid. Karena harga jual di pasar sekunder lebih tinggi dibanding harga parnya serta hasil investasi yang lebih besar dibandingkan bunga deposito bank yang hanya berkisar 6\% pertahun serta tingkat bagi hasil dan profit margin dari deposito pada bank syariah masih di bawah kupon Sukuk SR 001.

Adapun alasan variabel Artibut Produk Islami memiliki pengaruh terhadap Minat Berinvestasi SR 001 karena responden beralasan bahwa investasi SR 001 mampu memberikan kemakmuran terhadap masyarakat umum dan hasil investasi yang halal.

Indikator hasil investasi yang halal serta memberikan distribusi kemakmuran dari variabel Atribut Produk Islami telah dianggap benar oleh investor, sehingga mereka berminat berinvestasi pada SR 001. Selain itu indikator saling ridha dalam bertransaksi juga melatarbelakangi investor dalam menimbulkan minatnya.

Patut dicermati bahwa jumlah emiten sukuk di Indonesia dibandingkan dengan jumlah obligasi konvensional proporsinya tidak seimbang, serta 
potensi dana yang dapat dijaring melalui instrumen sukuk masih sangat besar, sehingga langkah pemerintah mengeluarkan sukuk SR 001 sangat tepat timing-nya untuk menjaring dana dari investor individu dan sukuk SR 001 merupakan SBSN pertama yang menggunakan prinsip syariah.

Adapun alasan investor memilih BSM dibandingkan agen yang lain karena kelebihan atau daya tarik yang dimiliki BSM menurut investor adalah profesionalisme serta operasionalnya sesuai syariah. Profesionalisme BSM dalam melayani investor berupa kemudahan dalam menjalani prosedur pembelian sukuk SR 001, dimana prosedur pemesanan pembelian sukuk SR 001 adalah: (1) Menghubungi BSM untuk melayani pemesanan pembelian Sukuk Negara Ritel; (2) Membuka rekening di BSM (jika belum mempunyai rekening) dan rekening surat berharga (jika diperlukan) pada bank kustodian anggota Subregistry atau Partisipan/Nasabah Subregistry (untuk sukuk SR 001 bank kustodiannya adalah Bank Bukopin); (3) Menyetor dana sesuai jumlah pembelian, minimal Rp. 5.000.000,- (lima juta rupiah) dengan kelipatan Rp. 5.000.000,- (lima juta rupiah) ke rekening "Sukuk Ritel" pada bank yang ditunjuk oleh BSM; (4) Mengisi dan menandatangani Formulir Pemesanan (FP01) serta melampirkan fotocopy KTP serta fotocopy bukti transfer dana; (5) Menerima tanda terima bukti pemesanan pembelian dari BSM; (6) Menunggu hasil keputusan penjatahan yang ditetapkan oleh Pemerintah untuk mengetahui jumlah Sukuk Ritel yang berhasil dimenangkan dan (7) Menerima konfirmasi kepemilikan Sukuk Ritel seri SR-001 sesuai dengan jumlah pemesanan pembelian yang berhasil dimenangkan dari BSM.

Kemudahan yang diberikan BSM berupa pelaksanaan prosedur tersebut di atas dapat dilakukan di kantor BSM yang tersebar di seluruh Nusantara, jadi investor tidak merasa kerepotan dalam proses pembelian sukuk. ${ }^{31} \mathrm{Di}$ samping itu adanya ikatan emosional antar sesama Muslim melalui pelaksanaan operasional BSM sesuai syariah menjadi backup dalam menumbuhkan keinginan investor untuk membeli sukuk SR 001 melalui BSM. Meskipun tidak dimasukkan dalam model koesioner, namun terlihat bahwa keseharian responden serta mayoritas agama yang dipeluk adalah Islam.

${ }^{31}$ Hasil wawancara dengan Eka Rahmawati, Customer Cervice BSM tanggal 1 Agustus 2010. 
Sehingga dapat disimpulkan persamaman multi regresi yang menyatakan hubungan antara variabel Risiko Investasi dan Atribut Produk Islami terhadap variabel Minat Berinvestasi SR 001 dinyatakan sebagai berikut: $\mathrm{Y}=-1,823+0,412 \mathrm{X}_{1}+0,879 \mathrm{X}_{2}$

Untuk itu dari hasil perhitungan tersebut maka dapat diinterpretasikan sebagai berikut: berdasarkan persamaan regresi terlihat bahwa paramater koefisien regresinya untuk variabel independen adalah positif, hal ini menunjukkan bahwa terdapat hubungan positif antara Risiko Investasi dan Atribut Produk Islami terhadap Minat Berinvestasi SR 001, sehingga setiap terjadi peningkatan X akan diikuti pula oleh peningkatan Y. Dengan kata lain semakin investor beranggapan Sukuk aman dari segala risiko investasi maka akan semakin mempengaruhi minat investor dalam berinvestasi, hal ini jumlah investor SR 001 akan mengalami peningkatan seiring niminya risiko investasi. Begitu juga dengan kekhasan atribut produk islami pada SR 001, dimana semakin tinggi derajat kekhasan atribut produk islami, maka semakin bertambah pula peningkatan jumlah investor SR 001.

\section{F. Kesimpulan}

Berdasarkan hasil penelitian dan pembahasan yang telah dilakukan dapat ditarik kesimpulan bahwa risiko investasi dan atribut produk islami berpengaruh positif terhadap minat masyarakat untuk berinvestasi, hal ini terbukti dari hasil uji statistiknya, secara Uji F maupun uji T. Adapun daya tarik yang dimiliki BSM menurut investor adalah alasan investor memilih BSM dibandingkan agen yang lain karena kinerja pegawai BSM yang profesional serta pelaksanaan operasionalnya sesuai syariah. 41,5\% responden memilih BSM dikarenakan oleh faktor atau alasan profesional. Posisi di bawahnya sebesar 29,3\% karena faktor BSM bank islami atau sesuai syariah, dan faktor kepercayaan menjadi alasan investor sebesar 19,5\% atau 8 orang responden. Mengacu pada hasil pengolahan data dan pembahasan, saran-saran yang dapat penulis berikan: (1) Untuk saat ini memang benar bahwa risiko investasi sukuk milik pemerintah tergolong kecil bahkan tidak ada. Hal ini tidak terlepas dari meningkatnya perekanomian Negara yang bergerak positif dan cenderung naik. Indonesia merupakan salah satu dari tiga Negara di kawasan Asia yang sanggup mempertahankan perekonomiannya di kala terjadi krisis keuangan global akhir 2008 lalu. Maka dari itu pemerintah terlebih Menteri Per- 
ekonomian senantiasa mempertahankan dan selalu meningkatkan perekonomian negara, agar investor pribumi khususnya investor sukuk SR 001 dapat merasakan manfaat investasinya; (2) Keyakinan investor akan penggunaan dana sukuk SR 001 mampu memberikan kesejahteraan bagi rakyat Indonesia mengidentifikasikan bahwa instumen islami terlebih konsep perekonomian Islam mampu menjawab permasalahan mengenai distribusi kemakmuran bangsa. Sebuah pertanggungjawaban yang tidak hanya tertera pada selembar kertas belaka, melainkan ada hubungan vertikal (pemerintah dengan Tuhan) maupun horisontal (pemerintah dengan investor). Maka dari itu implementasi dari konsep perekonomian berbasis syariah harus selalu ditingkatkan dan dikembangkan guna terwujudnya masyarakat yang sejahtera; (3) Bank Syariah Mandiri diharapkan meningkatkan profesionalismenya dengan berlandaskan ketentuan syariah. Karena dua hal inilah yang melatar belakangi investor lebih memilih BSM dibandingkan dengan agen yang lain. Disamping itu BSM merupakan satu-satunya agen SBSN yang landasan operasinya sesuai dengan syariah, sehingga kedepan mampu mengawal bank-bank syariah lain untuk menjadi agen SBSN; (4) Diharapkan BSM lebih meningkatkan cervice quality terhadap kepuasan nasabahnya, hal ini didasarkan atas penyebaran informasi yang positif akan dilakukan oleh nasabah loyal, dan loyalitas nasabah di peroleh dari cervice quality yang baik dari pihak BSM; (5) Diharapkan agar dilakukan penelitian lebih lanjut terkait dengan risiko investasi berbasis syariah serta pengenalan ragam atribut produk investasi islami baik berupa produkproduk yang tergoleng dalam pasar uang (money market) maupun pasar modal (capital market), karena banyak hal yang dapat digali seputar variabel yang diteliti sehingga akan memberikan masukan sekaligus manfaat bagi pihakpihak yang berkepentingan demi perkembangan sektor investasi berbasis syariah.[w] 


\section{BIBLIOGRAFI}

Brannen, Julia, Memadu Metodologi Penelitian Kualitatif dan Kuantitatif, terj. Huktan Arfawie Kurde, dkk,, Yogyakarta: Pustaka Pelajar dan IAIN Antasari, 2002.

Departemen Keuangan Republik Indonesia, Memorandum Informasi Sukuk Negara Ritel Seri SR 001, 2009, Departemen Keuangan Republik Indonesia, Jakarta.

Departemen Keuangan Republik Indonesia, Peraturan Pemerintah No. 57 tahun 2008 tentang Perusahaan Penerbit SBSN Indonesia, Direktorat Jenderal Pengelolaan Utang Departemen Keuangan Republik Indonesia.

Engel, F. James, Roger D. Blackwell, dan Paul W. Miniard, Perilaku Konsumen. Yogyakarta: Binarupa Aksara, 1994.

Fakhruddin, Hendy M, Istilah Pasar Modal A-Z, Jakarta: Elex Media Komputindo, 2008.

Fauziah, Nur dan Adistien Fatma Setyarini, "Analisis Faktor-faktor yang Mempengaruhi Yield Obligasi Perusahaan (Studi Kasus pada Industri Perbankan dan Industri Finansial)," Jurnal Siasat Bisnis, No. 9. Vol. 2, Jakarta, 2004.

Ghozali, Imam, Aplikasi Multivariate dengan Program SPSS, Semarang: UNDIP, 2001.

Aplikasi Analisis Multivariate dengan Program SPSS, Semarang: Badan Penerbitan UNDIP, 2005.

Hadi, Sutrisno, Metodologi Research 2, Yogyakarta: Andi Offset, 2001.

Harnanto, "Survei Minat Siswa SLTP Negeri dan Swasta Kecamatan Bantarkawung Kabupaten Brebes terhadap Ekstrakurikuler Bola Voli Tahun Ajaran 2004/2005," Skripsi, tidak dipublikasikan, Semarang: Universitas Negeri Semarang, Fakultas Ilmu Keolahragaan, 2006.

Hartono, "Pertimbangan Return dan Risiko dalam Keputusan Investasi," makalah disampaikan saat pengukuhan Prof. Dr. H. Hartono. M.S sebagai Guru Besar Universitas Sebelas Maret Surakarta 5 Maret 2010, diunduh pada web. http://pustaka.uns.ac.id/

Hasbi, Teungku Muhammad ash-Shiddieqy, Koleksi Hadis-hadis Hukum, Jil. 7, Semarang: Pustaka Rizki Putra, 2001. 
Husnan, Suad, Dasar-dasar Teori Portofolio dan Analisis Sekuritas, Yogyakarta: AMP YKPN, 2003.

Iswardono, Uang dan Bank, Yogyakarta: BPFE, 1996.

Jogiyanto, Metodologi Penelitian Bisnis: Salah Kaprah dan Pengalamanpengalaman, Yogyakarta: BPFE, 2004.

Junusi, Rahman, "Pengaruh Atribut Produk Islam. Komitmen Agama. Kualitas Jasa dan Kepercayaan terhadap Kepuasan dan Loyalitas Nasabah Bank Syariah (pada Bank Muamalat Kota Semarang)," paper dipublikasikan pada acara The 9-th Annual Conference on Islamic Studies (ACIS), Surakarta: 2-5 November 2009.

Koentjaraningrat, Metode-metode Penelitian Masyarakat, Jakarta: Gramedia Pustaka Utama, 1994.

Kotler, Phillip, Manajemen Pemasaran, edisi Bahasa Indonesia, Jakarta: Pearson Education Asia Pte. Ltd. dan PT. Prenhlmlindo.

Kuncoro, Mudrajat, Metode Kuantitatif: Teori dan Aplikasi untuk Bisnis dan Ekonomi, Yogyakarta: AMP YKPN, 2001.

Lewis, Mervin K. dan Latifa M. Algaoud, Perbankan Syariah Prinsip. Praktik dan Prospek, edisi terjemahan, Jakarta: Serambi Ilmu Semesta, 2005.

Moeliono, Anton M., dkk, Kamus Besar Bahasa Indonesia, Jakarta: Balai Pustaka, 1999.

Muhadjir, Noeng, Metodologi Penelitain Kualitatif, Yogyakarta: Rake Sarasin, 2002.

Muhaimin, "Korelasi Minat Belajar Pendidikan Jasmani terhadap Hasil Belajar Pendidikan Jasmani," Skripsi, tidak diterbitkan, Semarang: IKIP, 1994.

Muhamad, Dasar-dasar Keuangan Islami, Yogyakarta.: Ekonisia, 2004.

Prawiro, Radius, Pergulatan Indonesia Membangun Ekonomi Pragmatisme dalam Aksi, ed. Revisi, Jakarta: Primamedia Pustaka. 2004.

Rahman, Arif,, Pilihan Investasi Paling Mak Nyuss, Yogyakarta: Media Pressindo, 2009.

Ravallion, M., Poverty Comparisons, World Bank, 2001.

Saparinah, dkk., Psikologi Olahraga: Buku Tuntunan, Jakarta: Depdikbud, 1982.

Sekaran, Uma, Research Methods for Business, terj. Kwan Men Yon, Metodologi Penelitian untuk Bisnis, Jakarta: Salemba Empat, 2006.

Setyowati, Eni dan Siti Fatimah NH., "Analisis Faktor-faktor Yang Mempengaruhi Investasi Dalam Negeri di Jawa Tengah Tahun 1980-2002," Jurnal Ekonomi Pembangunan, Vol. 8, No. 1,2007. 
Singarimbun, Masri dan Sofian Efendi, Metodologi Penelitian Survai, ed. Revisi. Jakarta: LP3ES, 1989.

Sugiyono, Metodologi Penelitian Bisnis (Pendekatan Kuantitatif, Kualitatif, dan $R \& D$ ), Bandung: Alfabeta, 2008.

Suliyanto, Metode Riset Bisnis, Yogyakarta: Andi Offset, 2006.

Sumitro, Warkum, Asas-asas Perbankan Islam dan Lembaga-lembaga Terkait (BAMUI, Takaful dan Pasar Modal Syariah) di Indonesia, Jakarta: Raja Grafindo Persada, 2004.

Surat Pengumuman Hasil Penerbitan Sukuk Negara Ritel Seri SR 001 No. Peng00162/BEI.PSU/02-2009. Departemen Keuangan Republik Inonesia.

Syahyuti, "Review dari Sepuluh Penelitian tentang Berbankan Syariah," 2005, data diakses dari http:// www.undip.co.id, tanggal 10 Maret 2010.

Tim Penulis DSN MUI, Himpunan Fatwa Dewan Syariah Nasional, Jakarta: Intermasa, 2003.

Umar, Husein, Metode Riset Bisnis, Jakarta: Gramedia Pustaka Utama, 2002.

Undang-undang Nomor 10 Tahun 1998 tentang Perbankan.

Undang-Undang Republik Indonesia No. 21 Tahun 2008 tentang Perbankan Syariah, pasal 20, ayat 1 , poin e, pasal 24, ayat 1 , poin b.

Undang-Undang Republik Indonesia Nomor 19 Tahun 2008 tentang Surat Berharga Syariah Negara, Pasal 1, Ayat 1, 6, 7,8 dan 9.

Warde, Ibrahim, Islamic Finance In the Global Econimy, terj. Andriyadi Ramli. Islamic Finance: Keuangan Islam dalam Perekonomian Global, Yogyakarta: Pustaka Pelajar, 2009.

Whiteringten, H. C., Psikologi Pendidikan. terj. M. Buchari, Jakarta: Aksara Baru, 1982.

Widodo, Wahyudi, "Faktor-faktor yang Mempengaruhi Permintaan Obligasi Korporasi di Indonesia," Skripsi, tidak diterbitkan, Bandar Lampung: Universitas Lampung, 2009.

Wijaya, Krisna dan Djoko Retnadi, Konsolidasi Perbankan Nasional: Dari Rekapitalisasi Menuju Arsitektur Perbankan Indonesia (API), Jakarta: Masyarakat Profesional Madani, 2005. 